\title{
Threats to Global Health and Opportunities for Change: A New Global Health
}

\author{
Ulrich Laaser DTM\&H, MPH, ${ }^{1}$ \\ Leon Epstein MB ChB, $\mathrm{MPH}^{2}$
}

\begin{abstract}
The most recent phase of internationalization and globalization is characterized by the growing influence of non-governmental organizations that have had an impact on health. Key threats of strategic relevance for health, in addition to global warming, are the global divides in terms of demographic development and the burden of disease, social inequity, migration of populations, migration of health professionals, the inequitable terms of trade, and the consequences of the recent global monetary crisis. This paper addresses opportunities as set forth in the Millennium Development Goals, a revival of primary health care, and the necessary resetting of global aid in terms of international donor harmonization and national coordination, e.g., through a Sector Wide Approach (SWAp). We recommend: (1) A Global Code of Conduct for non-governmental organizations; (2) A renewed major effort of the United Nations community to achieve the Millennium Development Goals as planned; (3) Further development of the concept of SWAp's to put the receiving governments into the "driver's seat". To this end, the achievement of the Paris/Accra criteria is essential, i.e., (4) To strengthen the linkage between governments and donors with a priority for primary health care services; and (5) To compensate the "sending" countries for basic investments in the upbringing and education of migrating professionals.
\end{abstract}

Key Words: global health, global divides, global opportunities, international health cooperation, Millennium Development Goals

\footnotetext{
${ }^{1}$ Ulrich Laaser DTM\&H, MPH. Section of International Public Health (S-IPH) Faculty of Health Sciences, University of Bielefeld, POB 1001 31, D-33501 Bielefeld, Germany, Website: FPHSEE: http://www.snz.hr/fph-see

${ }^{2}$ Leon Epstein, Professor, Hebrew University-Hadassah, Braun School of Public Health \& Community Medicine, Jerusalem, Israel, E-mail at leon@hadassah.org.il.
}

Correspondence: Prof. Dr. med. Ulrich Laaser at email ulrich.laaser@uni-bielefeld.de 


\section{INTRODUCTION}

Modern public health emerged to address the challenges associated with urbanization and industrialization in Europe at the turn of the $18^{\text {th }}$ to the $19^{\text {th }}$ century. A new category of wage labourers was derived largely from impoverished rural folk, apprentices, and destitute women and children. Safety devices were unheard of and small children, sometimes literally chained to machines, toiled from dawn to dusk in dusty, noisy, unventilated workrooms, even exceeded by dreadful conditions in the coalmines. ${ }^{1}$ Living conditions and nutrition were directly related to high morbidity and mortality rates, leading to governmental commissions of enquiry, as in the United Kingdom. ${ }^{2}$ A rising tide of humanitarianism and social concern saw the rise of public health organizations at the municipal level, with sanitation and later food safety as its lead issues. The analogy between Europe some 200 years ago and the conditions of living and working of large populations in the developing world today is obvious, and from a global perspective, the challenges are similar.

The internationalization of health can be dated to the second half of the $19^{\text {th }}$ century stemming from colonial and commercial growth. The scientific era of public health based on the "Germ Theory" was established by the seminal work on the infectious genesis of cholera, tuberculosis, rabies, typhoid, hospital infections, and many other communicable diseases, pioneered by Robert Koch, Louis Pasteur, Ignaz Semmelweis, and Joseph Lister. In the wake of the colonization process, the relevance of public health across the entire globe came into focus and the first international regulations were negotiated. International cooperation in preventing the cross-border transmission of communicable disease was led by the International Sanitary Conferences held between 1851 and 1938. ${ }^{3}$

A third phase can be identified as beginning after the Second World War, mandating the large international organizations like the World Health Organization (WHO), the World Bank, and the International Monetary Fund. These institutions, though focused primarily on global economic structures, were all of high relevance for population health.

The present fourth phase is characterized by the growing influence of health-related non-governmental organizations (NGOs), (e.g., Medecins sans Frontières that was awarded the Nobel Price for Peace in 1999). In the area of global public health, the most important NGOs are the World Federation of Public Health Associations (WFPHA), the International Union for Health Promotion and Education (IUHPE), the International Association of National Institutes of Public Health (IANPHI), and the 
Associations of Schools of Public Health, still organized according to the WHO regions but not yet at the global level. During the next decade, one may expect an intensified cooperation and coordination among these global public health organizations; for example, WFPHA has established offices not only in Washington DC, but also in Geneva and Beijing.

An important development in modern public health conceptualization has been the recognition of the principle that it includes not only the classical elements of prevention in terms of environmental threats and spread of communicable disease, but also the planned action of health care systems in their responsibility for the health of all individuals that make up a community. Consequently, public health practice has extended, for example, to the primary prevention of chronic disease, its early diagnosis, and treatment in order to avoid disability in all its forms. This has brought about the realization that the community health clinic and the modern hospital are integral components of modern public health and as such, have a critical role in promoting population health, and can be considered as public health institutions.

Today, globalization is a common term. But why is it that we can observe globalizing processes and the emergence of a common global infrastructure just in our times, with global convergence facilitated by modern media such as television and Internet, as well as by mass rapid transportation, tourism and commerce? A major reason is the growing public awareness of life-threatening problems common to all of us, wherever we live in the more or the less developed regions of the Earth. Key threats of strategic relevance for health today are global warming, global divides, and global security.

All of these elements are closely interconnected just as global warming is a key cause of natural and man-made disasters, floods, water shortages, and desertification, contributing in turn to (civil) wars and imbalances (demographic and economic divides), which all too often result in poverty and hunger, impeding the health of entire populations. This chain of consequences flows in both directions; as noted by the Commission on Macroeconomics and Health (2000), ${ }^{4}$ an acceptable health status constitutes a precondition for economic development, which can reduce the risk of violent conflicts for scarce resources and of environmental damage.

In this paper, we focus on the threatening global divides and on the global opportunities for health improvement of the world population and do not discuss the complex issues of global warming and health, global security, and good governance. 


\section{GLOBAL THREAT TO HEALTH}

If health is a human right as defined in the 1978 Alma-Ata Declaration, ${ }^{5}$ then the global divides of health status constitute a gross injustice to the majority of the world population. It can be seen that the major global imbalances are interconnected: high fertility leading to poverty which is linked to high disease burdens and high outmigration, aggravated by trade protectionism of the highly developed countries, notably in the European Union and the United States, and heavily hit by the financial crisis of 20082010 .

\section{GLOBAL DEMOGRAPHY AND THE UNEQUAL BURDEN OF DISEASE}

The world population is increasing at the present annual rate of 1.13 percent (1990: 1.56 percent). Between 1959 and 2050, it will have tripled from 3 to 9 billion. ${ }^{6}$ Although the global growth rate is slowing since it peaked in 1962-1963 at 2.20 percent, most of the current growth is taking place in the poorest of developing countries. Sub-Saharan Africa likely will contribute the most people to its current population and will have 350 million by 2025 . However, in all regions, fertility rates are decreasing, from the highest level of 6.7 children per woman in Africa in 1955 to 5.1 in 2005, and in Asia, from 5.9 to 2.5. Europe stands at the lowest end with 1.4 children per woman in $2005 .^{7}$ The latter means that the European population is going to shrink as the fertility replacement rate is 2.1. The gap between countries with still high population growth and those with slow population growth or decline is linked to vast disparities in wealth, health, and opportunities (Table 1). ${ }^{8}$

Whereas the indicators of the wealthiest population segments in some countries (e.g., Peru or Nicaragua) come close to those in Europe and North America or are equal (e.g., 97 percent of the population completes the fifth grade of education in Peru), the poorest segments show indicator levels common in the developing world. Examples include a fertility rate of 8.5 in Uganda and completion of the fifth grade at 2 percent for female children in Mali.

The burden of disease is usually expressed in the form of Years of Life Lost (YLL), Years Lost to Disability (YLD), and Disability Adjusted Life Years (DALYs). Figure 1 shows the global distribution of these parameters: more than 500 DALYs/1,000 population in sub-Saharan Africa, as compared to less than 200 for high-income countries. ${ }^{9}$ The contrast is even greater, namely about 4:1, if YLL are considered separately. 
Table 1

Indicators of Fertility, Health, and Education for the Poorest $(P)$ and Wealthiest (W) Women in Selected Countries, Around the year 2000

\begin{tabular}{|c|c|c|c|c|c|c|c|c|}
\hline \multirow[t]{2}{*}{ Country } & \multicolumn{2}{|c|}{$\begin{array}{l}\text { Children per } \\
\text { woman }\end{array}$} & \multicolumn{2}{|c|}{ Infant mortality } & \multicolumn{2}{|c|}{$\begin{array}{l}\text { Women ages } \\
15-49 \text { using } \\
\text { modern } \\
\text { contraceptives } \\
\text { (percent) }\end{array}$} & \multicolumn{2}{|c|}{$\begin{array}{l}\text { Women } \\
\text { completed } 5^{\text {th }} \\
\text { grade of school } \\
\text { (percent ) }\end{array}$} \\
\hline & $\mathrm{P}$ & W & $\mathrm{P}$ & W & $\mathrm{P}$ & W & $\mathrm{P}$ & W \\
\hline Egypt & 4.0 & 2.9 & 76 & 30 & 43 & 61 & 22 & 91 \\
\hline Mali & 7.3 & 5.3 & 137 & 90 & 4 & 18 & 2 & 42 \\
\hline Nepal & 5.3 & 2.3 & 86 & 53 & 24 & 55 & 9 & 55 \\
\hline Nicaragua & 5.6 & 2.1 & 50 & 16 & 50 & 71 & 20 & 92 \\
\hline Peru & 5.5 & 1.6 & 64 & 14 & 37 & 58 & 47 & 97 \\
\hline Uganda & 8.5 & 4.1 & 106 & 60 & 11 & 41 & 24 & 82 \\
\hline Zambia & 7.3 & 3.6 & 115 & 57 & 11 & 53 & 41 & 95 \\
\hline
\end{tabular}

Note: Based on responses from women ages 15 to 49 .

Children per woman measures the total number of births a woman would have, given current birth rates.

Infant mortality refers to the number of deaths of infants under age 1 year per 1,000 births in a given year. The poorest and wealthiest women have household assets in the lowest and top fifths of the household wealth distribution.

Source: Gwatkin DR, et al. Initial country-level information about socio-economic differences in health, nutrition, and population. $2^{\text {nd }}$ ed. (2004). ${ }^{8}$

URL: http://siteresources.worldbank.org/INTPAH/Resources/IndicatorsOverview.pdf

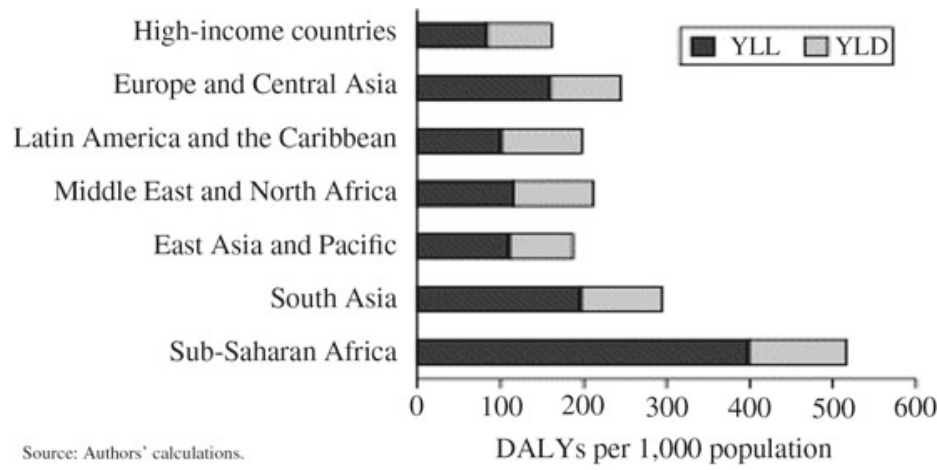

Fig. 1. YLL, YLD, and DALYs by Region, 2001.

Source: Mathers et al.9 Available from URL: http://www.ncbi.nlm.nih.gov/bookshelf/br.fcgi? book=gbd\&part=A176\#A323 
In these calculations, the burden and the cost of inequity of new emerging diseases (e.g., SARS, Avian Influenza, and H1N1 influenza) are probably underestimated. However, the list of all emerging and re-emerging diseases is much longer. ${ }^{10}$

In addition to the above appreciation of new emerging diseases, population aging is an important demographic and health transition, which affects global health and population aging to an increasing degree, and causes the concomitant rise in morbidity and mortality from chronic and degenerative diseases. It is especially a feature of the developed world, but has not bypassed the developing one. In relation to the latter, the double burden of communicable and chronic disease has become a major threat to population health and a challenge to health care systems.

\section{THE THREAT OF SOCIAL INEQUITY TO GLOBAL HEALTH}

The 1978 Declaration of Alma-Ata ${ }^{5}$ concluded that, "The existing gross inequality in the health status of the people, particularly between developed and developing countries, as well as within countries, is politically, socially, and economically unacceptable" and "Governments have a responsibility for the health of their people, which can be fulfilled only by the provision of adequate health and social measures".

Thirty years later the WHO Commission on Social Determinants of Health stated "Inequities are killing people on a grand scale."11 Their diagnosis of the causes of health inequities focuses clearly on the existing and growing social disparities between and within countries and the need to not only recognize this fact, but to act to reduce the differences. This will require substantial political will, and it does seem that little progress has been made over the past three decades.

One of the recommendations of the WHO Commission relates to the need for universal health care. ${ }^{11}$ However, even from the data that the Commission presented (e.g., in relation to the City of Glasgow in the United Kingdom, and from experience in Israel), it is clear that this universality alone is not enough. Therefore, while accepting the overriding importance of policy and action in relation to the defined social determinants, there is doubt as to the ability of the political powerbase to accept responsibility; even if it does, the change will take place over a long period 
of time. This begs the question: What will be the fate of health inequity in the interim? In an attempt to answer this question, the following short analysis concentrates on the role of the health care system (HCS) in general (hospital and community) and public health services in particular. However, it is important in any discussion of health inequalities to note that the implications for the individual, family, HCS, and society as a whole are not found solely within the health domain. It has moral, social, and especially economic implications. Concerning the latter, it is only recently that substantive research projects have attempted to assess the economic burden at a national and mutinational level, as illustrated in two studies in Europe and the United States. In the former, they calculated that, in the 25 countries of the European Union in 2004, the cost of health inequity, assessed by comparing the health and its economic implications of differential levels of education, was 9.38 percent of the gross domestic product (GDP) (980 billion Euros) and the cost to the health care systems was 1.7 percent of GDP or the equivalent of 20 percent of total health care costs. There was a calculated excess of 707,000 deaths due to this inequity. ${ }^{12}$

In the United States, La Veist et al. recently published an estimate of the combined cost of health inequalities and premature death in the United States, reporting the tremendous cost of health inequality both to society as a whole and the HCS in particular. According to their report, between 2003 and 2006 the combined costs of health inequalities and premature death in the United States were $\$ 1.24$ trillion. Eliminating health inequalities for minorities would have reduced indirect costs associated with illness and premature death by more than one trillion US dollars between 2003 and $2006 .{ }^{13}$ The HCS and specifically the health professionals working in it are affected both by the excess burden of potentially avoidable morbidity and mortality, as well as the waste of scarce resources that could be used to bolster the content and functioning of the services.

One of the essential functions of public health is to fulfill its advocacy role to improve the state of health of the population. In no area is this more relevant than in relation to health inequity. By acting on behalf of the defined population it serves, public health will direct its activities both externally, outside of the HCS, and internally to its Ministry of Health and health service organizations, and specifically to the health professionals and their representative organizations. The prevention of "waste" in both human and economic terms should be placed at the center of public health activity vis-à-vis the Government agencies in relation to their responsibility for reducing social disparity, as well as in relation to the many constituents of the HCS. 
What therefore is the specific role and responsibility of the HCS beyond its advocacy responsibility in stressing the importance of intersectoral action on the social determinants of health inequity?

- To prevent the health effects of socioeconomic and cultural inequality and inequity - especially through health promotion and disease prevention activities (primary prevention). For example, maternal education has been identified as a major risk factor for infant mortality, and female education is part of the Millennium Development Goals (MDGs). ${ }^{14-17}$ When a woman of low education visits a health service during pregnancy or takes her baby to the service during the first year of life, it is too late to change her level of formal education. The HCS must determine what action it needs to take in order to prevent the health effect (infant mortality) of the social risk (maternal education).

- To identify, treat and reduce existing health inequity by early diagnosis of disease, quality management of chronic disease, and rehabilitation (secondary and tertiary prevention). For example, low education or low income is related to the unsatisfactory control of diabetes. ${ }^{18}$ The HCS needs to provide data on this risk to its patients with diabetes and to develop the necessary and appropriate care for these high-risk individuals.

This is going to require a major adjustment of professional activity at all levels of the HCS and in all professions and all sectors of government. It will require focused intervention specifically directed at identified manifestations of health inequity in different regions and divergent population groups. The question does arise as to the major factors, within the HCS, that are related to the prevention or reduction of health inequity:

Equitable access: In many countries equitable access to quality health services is different either on a geographical basis or for specific population groups and relates both to the physical and human infrastructure. The Inverse Care Law defined by Tudor-Hart in 1971 states clearly, "that those whose health needs are greatest, and who are often to be found among marginalized groups in society, often have the worst access to care." ${ }^{19}$ It is still applicable almost 40 years later.

Financial Barriers: The ability to pay for health care should not be a barrier to obtaining quality care whether this is related to basic insurance or additional copayments. Payment for services, if required, should be income related. 
Cultural Barriers: Culture has been defined as "a set of distinctive values, beliefs, and perceptions that manifest themselves as human behaviour." It can therefore be said that any interaction between people of different cultures, especially between patients and service providers, must take into account these differences. A recent study in the United States of the factors responsible for the differential control of diabetes between Black and White patients found that it was not a result of different treatment provided to different patients, but that the same treatment was given to all without consideration of their cultural background. ${ }^{20}$ This resulted in different outcomes (diabetes control).

This is an aspect inadequately tackled in the Final Report of the WHO Commission on Social Determinants of Health. ${ }^{11}$ A detailed analysis of the factors involved in the attempt to reduce health disparities in a multicultural society is beyond the scope of this paper. However, it is clear that it requires the appropriate data in order to identify cultural risk (e.g., ethnicity, race, language) and critically, the appropriate training of health professionals in cultural competence. The importance of the provision of trained interpreters has also become apparent in many countries. It is clear that in most countries the population is made up of diverse cultural groups (not forgetting the very important "culture of poverty") and that this has been exacerbated in recent decades by the mass movement of people across borders. Adapting HCS content to cultural pluralism is an essential requirement for the prevention and reduction of health inequity. ${ }^{21}$

While there is a national responsibility in every country to plan and act in order to reduce socioeconomic diversity and thus impact on health inequity, the role of the HCS must not be neglected. It needs to be the moving force for action on the overall social determinants of health, as well as for change within the HCS that will prevent and reduce health inequity.

\section{MIGRATION AND RECRUITMENT}

The divide between poor and wealthy populations has led to previously unseen mass migration within and between countries, aggravated by violent conflicts as noted above. There are now about 200 million international migrants or 3 percent of the world's population living outside of their country for at least one year. More than half are in developed countries and there are, in addition, close to 26 million internally displaced persons and an estimated 16 million refugees (2007), 4.6 million of them Palestinians under the responsibility of the United Nations Relief and Works Agency for 
Palestine Refugees in the Near East (UNRWA) ${ }^{22}$ Remittances to developing countries have risen dramatically and now total $\$ 337$ billion, over twice the level of official development assistance. ${ }^{23,24}$ The map in Figure 2 displays the gross imbalance of global population densities (i.e., the potential for migration especially from Southeast Asia). ${ }^{25}$

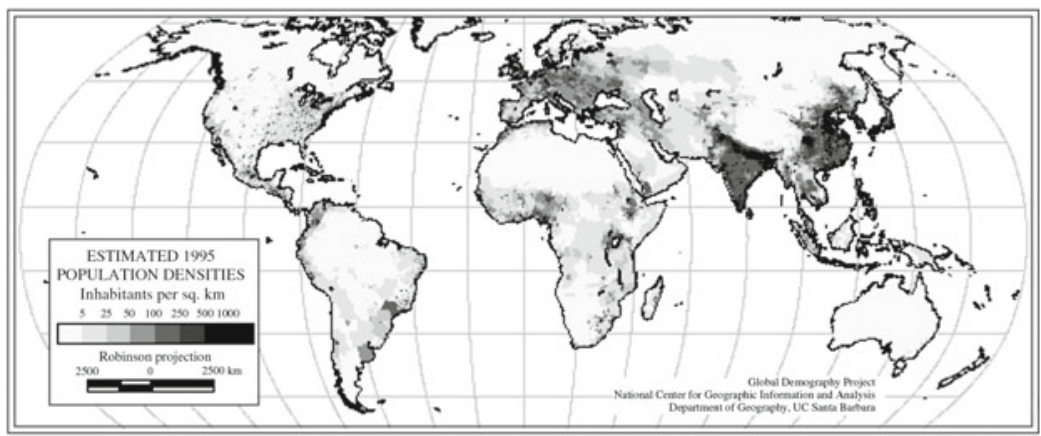

Fig. 2. Estimated global population densities (1995).

Source: National Center for Geographic Information and Analysis..$^{25}$ Available from URL: http:// www.ncgia.ucsb.edu/pubs/gdp/pop.html

As a consequence of the present economic downturn (2009/2010), opportunities for migrants have diminished in industrialized and industrializing countries. The gloomier prospects trigger return migration, in particular of temporary migrants, including irregular migrants. A consequence will be that migrant workers who lose their jobs will no longer be able to remit to their home regions and countries. Because some regions, countries, and numerous families heavily rely on these remittances, this will add to their difficulties.

Within countries, a movement from rural to urban zones can be observed worldwide. In 2025, about two thirds of the world's population will live in cities. In Europe today, about 90 percent of the population lives in cities of various sizes, but only two European cities - London and Paris - can be considered megacities with more than 10 million inhabitants. Megacities, however, are common in the so-called third world: more than 20 megacities will emerge worldwide by 2015 . To cite some examples, Lagos will increase from 0.3 million in 1950 to an estimated 24.6 million in 2015, Mexico City from 3.1 to 20.3 million and Beijing from 3.9 to 15.6 million. In the list of top urban growth rates, only Seoul, Tokyo, Los Angeles, and New York represent industrialized countries. Urbanization is not necessarily bad in and of itself. It only becomes a problem when the rate of urban 
population growth exceeds the capacity of the infrastructure to absorb and support it. ${ }^{26}$ Urbanization certainly alleviates certain problems, such as overpopulation, land shortages, and reduction of rural areas. On the other hand, there are costs in terms of increased poverty, the rise of slum and squatter areas, extremely unequal distribution of resources, overburdening of the urban infrastructure, and difficulties to supply megacities with the basic resources such as air and water. ${ }^{27,28}$

Indeed, the urban poor are the main group affected by an unequal distribution of resources, and they have to live in quarters characterized by the worst environmental conditions like overcrowded slums and squatter settlements close to polluting industries or congested roads. The physical conditions and population density make the planning and provision of appropriate health care an extremely difficult or impossible task. However, cities and metropolises have turned into the new centers of a polycentric world. As centers of an emerging global society, problems and conflicts, as well as solutions, become concentrated..$^{29}$

Rural-urban migration changes the demography of countries and continents not only quantitatively but also qualitatively, increasing differentials of health, education, and wealth. The more aggressive and better schooled workers in rural areas are often the first to move to urban places, reducing the social capita in the communities they left. This is the case even more so when the well educated upper class move from their less developed home countries to North America, the developed areas of the Western Pacific, or Europe to find a better life. In 2005, the WFPHA adopted a resolution requesting ethical restrictions on international recruitment of health professionals from low-income countries, ${ }^{30}$ acknowledging that the developed countries have 33.4 percent of the world's population, but they contain 74 percent of the world's physicians, 89 percent of the world's migrating physicians, and the vast majority of the 14,000 nurses moving across national boundaries each year. ${ }^{31}$ For example, there are only 750,000 health workers in all of sub-Saharan Africa, a region that serves 682 million people and suffers from 25 percent of the world's burden of disease. It has been estimated that Africa needs about 1 million more doctors, nurses, and midwives (as well as pharmacists and other categories of health professionals) to achieve the MDGs. ${ }^{32,33}$ There is of course the individual's right to leave their country of origin under the 1948 Universal Declaration of Human Rights; on the other hand, low-income countries should be compensated for the loss of health professionals as they have invested resources in their upbringing, schooling, and higher education for the benefit of other countries. ${ }^{34,35}$ 
The WFPHA recommends that health worker employers in developed countries, including public and private hospitals, long-term care facilities, and outpatient facilities, adopt a corresponding code of ethics including as a key request that health care facilities incorporating workers from abroad are strongly encouraged to manage recruitment and incorporation of health care workers from those countries in such a way that the sending country receives something in return. ${ }^{36}$ Reciprocal strategies of this nature could include sending developed country health workers in an exchange program, remunerating the source government for its investment in a workers' education program, or offering continuing education that a foreign health worker could apply in the home country. Therefore, higher income countries that receive significant numbers of health professionals from lower income countries shall invest in training and skills development in the sending countries, as a means of providing compensation for the loss of trained personnel. ${ }^{37,38}$ Since the WFPHA resolution was published in 2004, the international discussion has led to the draft WHO code of practice on the international recruitment of health personnel, though with softened requests for compensation to sending countries. ${ }^{39}$

\section{TRADE AND THE MONETARY CRISIS}

Generally the responsibility for setting trade policy and for negotiating trade agreements resides with the executive branch of government, with trade and finance ministers taking the leading role. While there is great variability among countries, health ministers, public health advocates, and civil society generally play a secondary role, and in some cases are not consulted at all. ${ }^{40}$ Services are traded under the General Agreement on Trade in Services (GATS), a World Trade Organization agreement that sets the rules for how services will be traded globally. Covered services include vital human services such as health care, water and sanitation, education, libraries, and energy, as well as finance, banking, telecommunications, distribution services, and construction, all of which have implications for health.

GATS is part of the General Agreement on Trade and Tariffs established in 1995 to "progressively liberalize" all services especially meant for strengthening services, trade, information, and exports of developing countries. ${ }^{41}$ This means reducing and eliminating the barriers to international trade in services that include both tariff and "non-tariff barriers to trade." Non-tariff barriers consist of a web of local, state, and national regulations on rights, the quality of services, professional licensing, and privacy, that 
protect safety, the environment, working conditions, and health, and can include public subsidies for vital human services such as health care and water. The health-related laws and regulations at stake include: clinician licensing; controls on the distribution of tobacco, alcohol, and firearms; data privacy rules (for example, patient health and billing information); requirements to allocate medical equipment and services based on need; health insurance regulations; environmental protections; occupational safety and health regulations; protections from hazardous materials; restraints on corporate ownership of hospitals; the ability of governments to maintain viable services in water and sanitation, and the safety of medical equipment.

GATS states that it excludes public services "provided in the exercise of government authority" if they are "supplied neither on a commercial basis nor in competition with one or more service suppliers." 41 Since some aspects of public services are frequently also provided in the private sector, or at least have commercial relationships with private suppliers, there is doubt that many services would actually be exempt under this definition. To be protected, vital human services must be specifically and permanently excluded from international trade agreements. Authority and accountability for population health need to be shifted back to health organizations. The principle of health before trade has to be applied to all trade negotiations.

The global imbalances discussed above are made worse by the global financial crisis that emerged in autumn 2008. The current crisis, beginning in the United States and then in the other OECD countries, is widely and progressively expanding to affect the most needy or the least developed and the developing countries. Depending on how severe this crisis will be and how long it continues, its negative health impacts on these countries are expected to be significant if not severe. ${ }^{42}$ Economic forecasts and speculations, which often prove to be misleading, indicate a significant drop in the GDP of most countries during 2009/2010, yet this impact will greatly differ between countries, linked to their dependence on exports, tourism, remittances and ties with the western banking and stock markets. ${ }^{43}$ Moreover, countries with significant dependence on foreign development assistance may expect a decline in this source of health funding. The adverse health impacts will mainly affect the most vulnerable, especially children, women, the elderly, and the poor. ${ }^{44}$ As an example, UNICEF estimated a rise in the below 5 mortality rate in East Asia and the Pacific of up to 11 percent based on historical data from the 1997 economic crisis when Thailand and Indonesia suffered from a drop of its GDP by 20 percent. ${ }^{45}$ 
The WHO High Level Consultation ${ }^{46}$ in January 2009 recommended a set of Actions, among them the most significant being:

- Coverage with health care or health insurance is far from being universal in many countries. This partial coverage is even eroding due to job losses. More uninsured can only result in delaying care until it's too late, when complications occur. Restoring coverage for the unemployed, including provision of essential drugs should be a priority for governments.

- High capital resources such as building more hospitals, tertiary care centers, and buying expensive medical equipment is often disproportionate in all health systems, but especially in underfunded ones, in which primary care, home care, and other essential services are neglected. Evidence-based planning and priority setting are essential to guide spending, focusing on primary care, prevention, and public health services.

It is interesting to compare these recommendations with those issued in 1999 during the international debt crisis, in many ways a forerunner of the present economic recession. ${ }^{47}$ The gap between rich and poor is growing at a dangerous and unprecedented rate, and the world's 225 richest people have achieved a combined wealth equal to the annual income of the poorest 47 percent of the world's people. ${ }^{48}$ Transfers of wealth from the poorest nations to the richest force struggling nations to cut essential spending on health and education to meet debt payments, resulting in increasing levels of hunger, sickness, poverty and environmental degradation. For every 1 United States Dollar (USD) that northern countries provide in aid, over 3 USD come back in the form of debt servicing. Debt relief would be an important step towards addressing the massive inequalities that currently deform our global relationships and enable debtor countries to make a fresh start towards genuine social and economic development. However, appropriate mechanisms need to be developed to ensure that debt relief translates into social, economic, and health improvements for citizens rather than propping up corrupt regimes.

\section{GLOBAL OPPORTUNITIES FOR HEALTH}

\section{The Millennium Development Goals}

In the foreword to the mid-term report 2009 on the MDGs, SecretaryGeneral Ban Ki-Moon writes: "Nine years ago, world leaders set farsighted goals to free a major portion of humanity from the shackles of extreme poverty, hunger, illiteracy and disease. They established targets for 
achieving gender equality and the empowerment of women, environmental sustainability and a global partnership for development...we have been moving too slowly to meet our goals. And today, we face a global economic crisis whose full repercussions have yet to be felt...Early indications are that, not surprisingly, the poor have suffered most from the upheaval of the past year. The numbers of people going hungry and living in extreme poverty are much larger than they would have been had progress continued uninterrupted." 48

Due to the lagging statistical monitoring systems, the analyses in the cited 2009 report are based mostly on the changes between 1990, 1999 and 2005, and sometimes 2006 or 2007, thus falling short of the mid-term assessment by up to 3 years (the correct mid-term point is 2008 during the period 2000-2015 as declared originally). Therefore, on the one hand, they do not consider the additional progress possibly made up to 2008 , while on the other hand, they are not yet affected by the global financial crisis becoming apparent in the fall of 2008. However, not only the UN SecretaryGeneral is expecting, as cited above, a significant impact especially on the first MDG on the eradication of poverty and hunger. This goal has been rightly listed first among the eight MDGs (see Table 2), because it is unlikely that the other seven goals can be achieved sustainably if poverty remains as widespread as it is today. A closer look reveals that the improvements up to 2005 are grossly variable between continents (Table 3) and countries, and also within countries, a finding that is true for the MDG achievements in general. ${ }^{49}$

\section{Table 2}

Millennium Development Goals of the United Nations, 2000-2015

Goal 1: Eradicate extreme poverty and hunger

Goal 2: Achieve universal primary education

Goal 3: Promote gender equality and empower women

Goal 4: Reduce child mortality

Goal 5: Improve maternal health

Goal 6: Combat HIV/AIDS, malaria and other diseases

Goal 7: Ensure environmental sustainability

Goal 8: Develop a Global Partnership for Development

Source: United Nations Development Programme, http://www.undp.org/mdg/basics.shtml (Accessed 28 April, 2010).

Note: The MDGs: The 8 MDGs break down into 21 quantifiable targets that are measured by 60 indicators. 
Table 3 indicates that the 2015 goal of 21 percent living below an adapted poverty line of 1.25 USD was in reach in 2005; however, this is calculated from a baseline set at 1990 (i.e., a decade before the MDGs were declared). If one compares the progress between 1990 and 1999 of 11 percentage points to the progress between 1999 and 2005 of 6 percentage points, then it becomes apparent that the pace of development has been exactly the same before and after the MDG commitment ${ }^{50}$ in the year 2000. In addition, the largest chunk of progress is due to the overachievement of China, which not only halved, but quartered its poorest population. For the "lost" continent of sub-Saharan Africa, progress is close to none. Even in Southern Asia (including India), poverty reduction does not account for more than 3 percent points, leaving the region with 39 percent living below the poverty line, far from the target of 25 percent. The only region indicating a clear worsening, though at a relatively low level, is Western Asia (i.e., the Near East) with percentages rising from 2 to 6 percent. Furthermore, the proportion of vulnerable employment (i.e., own-account and contributing family workers) in total employment is likely to rise to about two thirds in 2008. No progress at all has been achieved with regard to the proportion of undernourished population, at 17 percent in 2008 as compared to 20 percent in 1991, far from the goal of 10 percent in 2015.

Table 3

MDG 1, Target 1: Halve, between 1990 and 2015, the proportion (\%) of people whose income is less than 1 USD a day

\begin{tabular}{l|c|c|c|c}
\hline REGION & $\mathbf{1 9 9 0}$ & $\mathbf{1 9 9 9}$ & $\mathbf{2 0 0 5}$ & Target 2015 \\
\hline Developing regions together* & 42 & 31 & 25 & 21 \\
Sub-Saharan Africa & 57 & 58 & 51 & 29 \\
Southern Asia (Indian subcontinent incl. Iran) & 49 & 42 & 39 & 25 \\
South-Eastern Asia (Indonesia, Philippines etc.) & 39 & 35 & 19 & 20 \\
Eastern Asia (i.e., China) & 60 & 36 & 16 & 30 \\
Latin America \& the Caribbean & 11 & 11 & 8 & 6 \\
Western Asia (i.e., the Near East) & 2 & 4 & 6 & 1 \\
CIS & 3 & 8 & 5 & 2 \\
Northern Africa & 5 & 4 & 3 & 3 \\
South-Eastern European transition countries & 0 & 2 & 1 & 0 \\
\hline
\end{tabular}

Note: Poverty is taken as the proportion (\%) of people whose income is less than 1 USD a day (a poverty line of 1.25 USD is used in the MDG 2009 report from which this table has been adapted, reflecting the decrease of currency exchange rates).

* All but the European Union, Northern America, Australia, New Zealand, Japan.

Source: François Bourguignon et al. ${ }^{49}$ 
The data on mother and child health (Table 4) are appalling, especially with regard to maternal mortality, which shows improvement in all regions (not indicated here) but overall only by 6 percent from the level in 1990. As high maternal mortality is mainly determined by access to and quality of obstetric medical services, this supports the notion that the medical infrastructure in the developing world has not substantially been improved during the last two decades in spite of a considerable number of externally financed health systems development projects. For comparison, the infant mortality rate in the developed countries was 11 and 6 percent in 1990 and 2007, respectively, and the maternal mortality rate accounted for 11 and 9 percent in 1990 and 2005, respectively.

\section{Table 4}

MDG 4: Reduce by two-thirds, between 1990 and 2015, the under-five mortality rate (per 1000 live births). MDG 5, target 1: Reduce by three quarters, between 1990 and 2015, the maternal mortality ratio (per 100,000 live births)

\begin{tabular}{l|c|c|c|c}
\hline REGION & $\mathbf{1 9 9 0}$ & $\mathbf{1 9 9 9}$ & $\mathbf{2 0 0 5}$ & Target 2015 \\
\hline MDG 4 & & & & \\
Developing regions together* & 103 & & 74 & 34 \\
Sub-Saharan Africa & 183 & & 145 & 61 \\
\hline MDG 5 & & & & \\
Developing regions together* & 480 & 450 & & 120 \\
Sub-Saharan Africa & 920 & 900 & & 230 \\
\hline
\end{tabular}

Source: Bourguignon F, et al. Millennium Development Goals at Midpoint: Where do we stand and where do we need to go? European Commission. 2008. ${ }^{49}$

As for Goal 6, on combating HIV/AIDS, malaria, and other diseases (especially tuberculosis), progress is slower than expected. Mainly due to wider access to treatment, the number of newly infected HIV cases shows a downturn from its height of 3.5 million cases worldwide in 1996 to below 3 million. Nevertheless, today in a country like Lesotho, 28 percent of the population below the age of 18 has lost one or both parents due to HIV infection. In regards to malaria, nearly a million people still die each year, mostly young children in sub-Saharan Africa. However, seemingly successful campaigns are under way making use of bed nets and artemisinin-based therapeutic combinations. For the third of the big three infectious diseases, namely tuberculosis, we find an overall reduction from 370 to 234 cases per 100,000 between 1990 and 2007, but an increase in sub-Saharan Africa 
from 333 to 421 and in the CIS countries, from 76 to 112 (excluding HIV positive patients) as compared to 14 in the developed regions. ${ }^{48}$

Four of the MDGs are direct health goals (reducing child mortality, improving maternal health, combating HIV/AIDS, malaria and other infectious diseases, and enhancing environmental sustainability). The other four goals are strong health determinants (eradication of extreme poverty and hunger, universal primary education, gender equity and women empowerment, and global partnership for development). ${ }^{48}$

In summary, it can be assumed that the health related MDG targets for Goals 1, 4, 5 and 6 are unlikely to be achieved in spite of some sluggish progress. Also, it is obvious that the economic growth of 4 percent in the developing regions between 2000 and 2007 did not translate directly into better population health. As Bourguignon et al. state, "The low correlations between growth and MDG achievements show that growth is necessary, but not sufficient for a sustainable MDG strategy. It has to be complemented with the appropriate sectoral policies." ${ }^{39}$ As seen from the mid-term point, the world is at risk of losing an opportunity. It needs to be stressed (Section 2.1.2) that the tremendous problem presented by health inequity will not be reduced if there is no substantial impact on population poverty.

Moreover, the MDGs are obviously lacking the achievement of peace as a fundamental development goal. Regional and local wars are waxing and waning in many parts of the world. Arms are abundant and available in many countries where food is scarce and people are suffering from hunger and undernutrition. ${ }^{42}$

\section{THE RENAISSANCE OF PRIMARY HEALTH CARE: DO WE NEED ANOTHER ONE?}

Primary health care (PHC) came of age and received international recognition and acceptance as a central and major constituent of the Health Care System in all countries at the 1978 Alma-Ata Conference. The Charter stated "Primary health care is essential health care based on practical, scientifically sound and socially acceptable methods and technology made universally accessible to individuals and families in the community through their full participation and at a cost that the community and country can afford to maintain at every stage of their development in the spirit of self-reliance and self-determination. It is the central function and main focus of the country's health care system." ${ }^{5,51}$

There were a number of additional factors that were included in the Charter that have important implications for PHC. These were the 
unacceptability of health inequity; the responsibility of governments for the health of all in their population through the provision of adequate health and social measures; a recognition that PHC addresses the main health problems of the community (and not only those of individuals coming for care); and that it requires, in order to achieve its objectives, the coordinated efforts of other sectors (e.g., agriculture, food, industry, housing, and others).

Three decades later (2008) it is clear that, while there have been many developments in the delivery of PHC, it cannot be said that it has achieved the lofty vision and objectives delineated in Alma-Ata. ${ }^{52}$ There have been many reviews that have attempted to analyze why the euphoria of $1978 \mathrm{did}$ not lead, at a global level, to PHC being at the center of health system functioning, and more importantly, did not bring about the health effects that were deemed critical. Acknowledging that the following short review is selective, it is of relevance to highlight some of the factors and conclusions of certain reviews.

I. WHO Review. Sixteen years after the Alma-Ata Conference, WHO published a paper entitled "Primary health care concepts and challenges in a changing world: Alma-Ata revisited", reviewing the Declaration of Alma-Ata and the recommendations of the conference. ${ }^{53}$ The overall assessment was that there had been a movement in the right direction at international and possibly national levels in attempting to achieve the goal of Health for All (HFA). However, the ideas and actions had not permeated sufficiently to the local level where change was really needed. The "top-down" approach was not sufficient to create change at the local level. Furthermore, there was a lack of clarity as to the sources of funding for the changes required and that where they had been forthcoming, in the private sector, issues of equity had arisen. Linked to this, ongoing health care reforms that focused on efficiency had the potential of worsening inequities in health and in health care. Four key areas of activity were defined that required changes in the PHC strategies. There needs to be:

- A "Code of Ethics" that would provide the basis for the social contract that would lead to HFA. This would include a health care focus on the underprivileged and reduction in health inequities; an overall improvement in health; and health care that improves health of individuals, families and communities;

- Special efforts to increase health equity by targeting those in the lower socioeconomic groups;

- Improve the quality and the effectiveness of health services in both the private and public sectors; 
- A reassessment of priorities in relation to health in order to meet the overall objective of improvement in health at all levels of society.

II. Alma-Ata 1978 Conference Follow-up. In 1998, a meeting was held in Almaty, Kazakhstan to celebrate the 20-year anniversary of Alma-Ata. The report "Primary health care 21: everybody's business" ${ }^{54}$ reviewed what had occurred in the interim years. The following were some of the conclusions:

- Health has improved and the essentials of PHC have been extended to many populations. PHC has been accepted as part of core health policy in many countries.

- Progress has been inequitable. Health status has deteriorated in some countries and/or in regions of countries.

- Inadequacies in PHC may explain part of the above deterioration. Vertical health programs directed to specific disease entities have gone against the principles of PHC. This has been related to funders adopting a top-down approach which has not been coordinated with the overall PHC (or health services) policy.

- External political and social changes - globalization, commercialization of health care, lack of political commitment - have increased the population diversity in health and health care.

In relating to the European Region of WHO, the then Director-General, Dr JE Asvall, wrote, "The beginning was not encouraging! When the Regional Office wrote to all the then 33 Member States of the Region and asked their opinion about the Alma-Ata Declaration and what they intended to do with it, the answer was very clear: this is an excellent idea - for everyone else but us! We in Europe have first class hospitals and good health services and do not need primary health care - thank you." 55

It should be stated (by one who was there in 1978 - LE) that this attitude was already evident at Alma-Ata in 1978 where many of the developed, industrialized countries did not see the need but went along with the decision for the other "less fortunate countries"(Epstein LE-personal communication).

Dr Halfdan Mahler who had been the Director-General of WHO at the time of the 1978 Alma-Ata Conference stressed that the concepts of PHC and its content had not changed since.$^{56}$ However, he indicated that in relation to certain basic issues, progress had not occurred or was insufficient:

- Insufficient financial resources were impeding equitable solutions to health problems of the population.

- There was still a lack of objective scientific evidence for preventive, treatment, and rehabilitative actions that is central to PHC content. 
- Health care systems are not able to provide appropriate interventions to all those at risk; these are generally available early in the disease development (i.e., when needed) and are efficient.

A major message in 1998 was that, while there had been progress, it was very uneven, and it was more in the field of policy than action. Furthermore, there needed to be a greater appreciation of the dangers to health as a result of globalization and its implications for health equity. The goal of PHC to reach HFA would not be achieved without major investments in health and in the human resources required to bring about change.

III. The 2008 WHO World Health Report once again placed PHC at center stage on the $60^{\text {th }}$ anniversary of WHO and the $30^{\text {th }}$ anniversary of AlmaAta. ${ }^{52}$ In her opening message, Dr Margaret Chan, the Director-General of WHO, highlighted the need to direct WHO's message towards PHC. She stated that there is a growing demand for PHC worldwide and the need on the part of policy makers for information as to how health systems can become more equitable, inclusive, and fair. In stressing the need to learn from the past while looking to the future, she identified four sets of reforms that need to take place to narrow the gap between "aspiration and implementation". They are (quote):

- Universal coverage reforms in order to contribute to health equity, social justice, and the end of exclusion.

- Service delivery reforms that will reorganize health services around people's needs and expectations.

- Public policy reforms that will integrate public health actions with primary care.

- Leadership reforms that will recognize the need for leadership based on negotiation between the players at all levels so that it will be possible to handle the complexity of present day health services.

These are needed to bring performance in the field in line with the lofty aspirations of Alma-Ata, which have not fundamentally changed, but have not been realized. In contemplating these documents, despite the fact that there has been a degree of change, with significant variation between and within countries, the concepts of PHC and the goals of HFA that were defined cannot, 30 years later, be considered to have been achieved.

Accepting the complexity of health care delivery and the vastly different structure and sociopolitical framework of systems worldwide, what are the reasons that we are not further along the road that was aspired to in 1978? The following is a short reflection on the factors that have been involved and the possible change required: 
- There is still not a total acceptance by all Governments and at all levels of society of the important constituents of the Alma-Ata Declaration.

Health is a fundamental human right;

Attainment of the highest possible level of health is an important social goal that is dependent on the actions of many social and economic systems, not only on health;

Health inequality exists and is growing in many places - it is unacceptable politically, socially, and economically;

Health status is of central importance to sustained economic and social development and to quality of life; and

Governments have a responsibility for the health of their people.

It therefore seems that an acceptance of these statements is a prerequisite for appropriate planning of future PHC that will otherwise continue (where it exists) as a very partial answer to the health needs of populations. This is certainly the responsibility of government in general and the health system decision makers in particular. WHO has a major role to play in its relationship with member countries.

- Health care in general and PHC in particular need to move from being almost entirely individually oriented and answering the sickness needs of those coming to it - to being responsible for the health of the entire population at all levels of prevention:

Primary, including health promotion and disease prevention;

Secondary, including early diagnosis of disease and appropriate treatment in line (as far as possible) with a proven scientific base;

Tertiary, including the prevention of complications and disability, and available rehabilitation.

There should be a clear understanding that these levels include the totality of health care (i.e., both in hospital (all forms), community health services and traditional public health actions), and are a sine qua non of the defined responsibility of both public and private health services. The planned integration of the levels of prevention and the activities of a wide range of service formats is a major challenge for government in general and the HCS in particular.

- However, it is not sufficient to declare formally that the HCS is responsible for the provision of health care to all those in need. What is needed is both a concept and the methodology for carrying it out. In essence, this requires a "marriage" of the principle of responsibility for the health of the total population (which is public health), with 
community based clinical primary health care. This has been done in the development of "Community Oriented Primary Care" (COPC) as conceptualized originally by Sidney Kark in rural South Africa in the 1940s and later developed in Jerusalem..$^{57-59}$ The concept of COPC has been accepted widely as a feasible approach to all levels of community health care. Its principles have been defined and methodologies tested - they have to be adapted to the reality of PHC in different countries and societies.

Renewed interest and stress on PHC is discussed by Rittenhouse et al and in this issue by Shortell et al, Tulchinsky and Varavikova, and Bandawala et al. ${ }^{60-63}$ All the reviews of PHC in recent years have stressed the critical need for valid and up to date data that can form the basis for planning and especially for coverage of all those in need of care. The expanding era of computer technology provides the framework for the availability of such information. An example of such usage is the "Quality Indicators for Community Health Care in Israel" project that routinely assembles data from the four Israeli health management organizations (HMOs) and provides data on a large series of health measures on the entire insured population of the country. ${ }^{18}$ This information has provided both the opportunity and incentive for the HMOs to introduce interventions in their community health services in order to rectify identified problems in the provision of community-based health care

There is clearly a need for change in the content of training of health professionals in PHC - physicians, nurses, social workers, administrators, and others such as community health workers. It is no longer sufficient to have a basic clinical training, even with Family Medicine specialization. The concept of responsibility for the health of the community, and not only the individual patient, will require the inclusion of epidemiology, biostatistics, social and behavioral sciences, and health economics in the training programs of PHC professionals in undergraduate and graduate education.

In conclusion, is it a renaissance of PHC that is required? If the implication is that a revival of PHC is needed, then it depends on what will be revived. The original Alma-Ata Declaration is as appropriate in 2010 as it was in 1978. What is needed is not more of the same but rethinking of the factors discussed above, their acceptance as a basis for national policy by government and the health care system alike, and planned realistic interventions that will provide PHC services with the ability to answer population health needs and bring us to the realization of Health for All. 


\section{RESETTING GLOBAL AID}

The steep global gradient between rich, highly developed countries and the poor, least developed countries is well known. With a few exceptions, the low GDP per capita goes hand in hand with limited access to food and water, low housing standards, incomplete educational coverage, high levels of (hidden) unemployment, and high emigration. Not surprisingly, limited access to and low quality of health care services and population health measured as (healthy) life expectancy also run in parallel.

\section{International coordination}

Aid to developing countries is therefore perceived as a moral obligation that is more often declared in speeches and resolutions than in deeds. A target of 0.7 percent of the GDP of economically developed countries for official development assistance (ODA) was first pledged 35 years ago in paragraph 43 of the 1970 UN General Assembly Resolution and has since been affirmed in many international agreements over the years, including the March 2002 International Conference on Financing for Development in Monterrey, Mexico. ${ }^{64}$ In paragraph 42 of the Monterrey Consensus, world leaders reiterated their commitment, stating: "we urge developed countries that have not done so to make concrete efforts towards the target of 0.7 percent of gross national product (GNP) as ODA to developing countries." The reality, however, is as follows: the largest national donors are the US, followed by Germany, Britain, and France with 26.0, 13.9, 11.4 and 11.0 billion USD in 2008. However, as a percent of their GDPs, the US does not even reach 0.2 percent and the other three leading ODA donors only reach close to 0.4 percent, which corresponds also to the general EU average. Only the Scandinavian countries - with the exception of Finland - exceed the 0.7 percent target. ${ }^{65}$

However, development assistance for health (DAH) has quadrupled since 1990 from 5.6 billion USD to 21.8 billion in 2007. Private foundations and NGOs shift the paradigm of global health aid away from governments and agencies like the World Bank and the United Nations and now make up a large piece of health assistance (Table 6). There are, however, serious imbalances between DAH and the burden of disease as shown by Ravishankar et al. in 2009. ${ }^{66}$ It has been obvious that for the last decade, DAH has been given not according to the highest disease burdens but by other criteria such as political and economic interests. One of the obvious reasons for imbalances is the extreme fragmentation and resulting ineffectiveness of international aid. Globally: 280 agencies, 242 multilateral 
funds, 24 Development Banks, 40 UN Organizations, and thousands of NGOs can be identified. Thus, for example, in East Timor (ca. 1 million population), there are more than 1200 donor initiated studies or 1 study on average for less than 1000 inhabitants. ${ }^{67}$ That is a better coverage than the number of physicians in many rural regions in the world (in East Timor, 1 physician statistically had to serve a population of 10,000 in 2004). ${ }^{68}$ In 2007, donors made more than 15,000 visits to 55 partner countries. Vietnam alone received 782 missions in 2007, more than two per working day. In the 1990s, Tanzania was grappling with over 1,500 projects in the health sector - each with its own reporting and oversight mechanisms. For under-resourced ministries in developing countries, these transaction costs can be unbearably high and reduce the value of the aid they receive to almost none. The sheer number of activities creates the need for greater harmonization between donors and alignment with partner country priorities. ${ }^{69}$ Especially in the indispensable state sector, knowledge and skills to secure coordination and collaboration in public health are limited.

The temptation for beneficiary countries to accept international aid without conditions often disrupts national priorities, as is the case if money comes too easily as in some EU funded programs. For example, loans from the World Bank - though at low interest rates - often create an underestimated burden in later years. Loans have two sides: Money is available now but has to be repaid later (especially if by others, i.e., taxpayers in the next generation). In addition, the money mainly returns, via expert fees and purchase of equipment, back to the crediting countries. The resulting question is rarely asked: Is the long-term outcome worth the (national) investment? The answer depends on the structural sustainability of projects, which is often impaired by the limited funding perspective of 2 or 3 years and disconnection of potential follow-up projects.

However, two conferences, Paris 2005 and Accra 2008, indicated some behavior change of both donor and recipient countries. Nevertheless, the progress seems to be too small to reach the envisaged targets in 2010 (Table 5). Progress has been made for only 3 indicators (2, 4 and 8). Most notably, the reliability of the public financial management systems in the recipient countries has improved in line with the target goals and untying aid has further improved as earmarking is increasingly seen as unethical (although often indirectly continued by expert induced demand). Given the only marginal achievements as regards the rest of the indicators including those relating to coordination, the success in aligning and coordinating technical assistance (indicator 4) seems to be questionable. One of the key desiderata (i.e., the coordination between donors and between government and donors) 
has made little to no progress as demonstrated by indicators $3,5 \mathrm{a}, 5 \mathrm{~b}, 6$ and 9. Likewise, the transaction costs for recipient countries by multiple missions (10a) and country studies (10b) are unchanged. Therefore, the responsibility for improvement now rests with the donors, as was stated at the follow-up conference in Accra.

Table 5

The Paris Indicators on Aid Effectiveness

\begin{tabular}{c|l|c|c|c}
\hline No. & \multicolumn{1}{|c|}{ Indicator } & 2005 Baseline & $\mathbf{2 0 0 7}$ & $\mathbf{2 0 1 0}$ Target \\
\hline 1 & Operational Development Strategies & 17 & 24 & 75 \\
\hline 2 & $\begin{array}{l}\text { Reliable Public Financial Management } \\
\text { Systems }\end{array}$ & $-/-$ & 36 & $\begin{array}{c}50 \% \\
\text { of countries } \\
\text { improve score }\end{array}$ \\
\hline 3 & $\begin{array}{l}\text { Aid Flows are recorded in countries' } \\
\text { budgets }\end{array}$ & 42 & 48 & 85 \\
\hline 4 & $\begin{array}{l}\text { Technical Assistance is aligned } \\
\text { \& coordinated }\end{array}$ & 48 & 60 & 50 \\
\hline $5 a$ & $\begin{array}{l}\text { Donors use country Public Financial } \\
\text { Management Systems }\end{array}$ & 40 & 45 & 80 \\
\hline $5 b$ & Donors use country procurement systems & 39 & 43 & 80 \\
\hline 6 & $\begin{array}{l}\text { Donors (do not) avoid parallel Project } \\
\text { Implementation Units (PIUs) (number) }\end{array}$ & 1817 & 1601 & 611 \\
\hline 7 & Aid is more predictable & 41 & 46 & 71 \\
\hline 8 & Aid is untied & 75 & 88 & $\begin{array}{c}\text { Progress } \\
\text { over time }\end{array}$ \\
\hline 9 & $\begin{array}{l}\text { Donors use coordinated mechanisms } \\
\text { for aid delivery }\end{array}$ & 43 & 47 & 66 \\
\hline $10 \mathrm{a}$ & Donors coordinate their missions & 18 & 21 & 40 \\
\hline $10 \mathrm{~b}$ & Donors coordinate their country studies & 42 & 44 & 66 \\
\hline 11 & Sound frameworks to monitor results & 7 & 9 & 38 \\
\hline 12 & Mechanisms for mutual accountability & 22 & 26 & 100 \\
\hline
\end{tabular}

Note: Percent Achievement as in Accra 2008, except for no. 6.

Source: Adapted from Deutscher and Fyson. ${ }^{69}$

For DAH, the relative weight of donor mechanisms has been changing in recent years, especially with the emergence of large private foundations and NGOs (Table 6). Together they made up 41.3 percent of DAH in 20062007, whereas the UN agencies and development banks reduced their share 
from over 50 percent in the 1990 s to 21.2 percent in 2007 . However, in line with the negligible progress on coordination between donors as indicated in the table above, aid through bilateral channels increased from 27.1 percent in 2001 to 34.0 percent in $2007 .{ }^{66}$

Table 6

Funding Channels of Development Assistance for Health (Percent Share of Total DAH)

\begin{tabular}{l|c|c}
\hline \multicolumn{1}{c|}{ DONOR CATEGORY } & Last Decade & Recent \\
\hline UN Agencies & $32.3(1990)$ & $14.0(2007)$ \\
World Bank and regional banks & $21.7(2000)$ & $07.2(2007)$ \\
Aid through bilateral channels & $27.1(2001)$ & $34.0(2007)$ \\
Global Fund & & $08.3(2007)$ \\
GAVI & & $04.2(2007)$ \\
Bill \& Melinda Gates & & $03.9(2007)$ \\
Funds channeled through NGO's & $13.1(1990)$ & $24.9(2006)$ \\
\hline
\end{tabular}

Source: Adapted from Ravishankar et al, 2009. ${ }^{66}$

\section{National Coordination}

As has been outlined already, especially in developing and transitional societies, coordinating capacities and competences are limited when facing a complicated and time consuming process of implementing international and bilateral aid efficiently. In addition, international, and to an even greater extent bilateral aid, often disrupts coherent national development plans and priorities.

The problem of the lack of coordinating capacity became known in the nineties and proposals to cope with it were developed. One of the most promising, though rarely implemented concepts, is the Sector-Wide Approach (SWAp) ${ }^{70-71}$ The SWAp can be described as an arrangement whereby donors work with governments to deliver a commonly agreed health policy and strategy, with the view to build ownership, enhance aid effectiveness, and reduce transaction costs.

A more operational definition reads as: All significant funding for the sector supports a single sector policy and expenditure program, under government leadership, adopting common approaches across the sector, and progressing towards government procedures to disburse and account for all funds. ${ }^{72}$ In exchange for giving up the right to choose projects according to their own priorities, donors gain a say in the development of 
national health policies and in decisions about how both external and domestic resources are allocated. However, the SWAp's approach is not a blueprint but a programmatic focus on the intended policy, a direction of change rather than a specific program attainment. The working definition thus focuses on the intended direction of change rather than just the current attainment.

One of the key principles and underlying mechanisms of a successful SWAp is an agreement on binding financial mechanisms. Resources will be channeled increasingly through government systems (not parallel ones of donors) (e.g., a project implementation unit (PIU)), and consolidated into joint accounts with a view towards overall budgetary support. Common disbursement, accounting, reporting, auditing, and procurement systems are to be defined. Development budgets and recurrent budgets have to be separated. Those donors not participating in a basket approach (financial envelope for a common agreed program filled by various donors) should however not be excluded but rather integrated through a wider forum of interested parties. ${ }^{73}$

However, even a sectoral program for the health sector may not consider transversal interdependencies and the complexity of a social sector like health. Therefore, ideally at a higher level, intersectoral coordination also has to be taken into account according to the principle of health in all policies, while not losing sight of subsidiarity. If all activities will be under one common sector-wide program, fully costed, and integrated into a medium term expenditure framework (MTEF), the Ministry of Health becomes accountable to the population and not just to donors.

\section{CONCLUSIONS AND RECOMMENDATIONS}

The main purpose of any health system should be to continuously reduce the impact and burden of illness, injury, and disability and to promote and improve the health and the health related autonomous functioning of the people. Health systems have a broader scope since they incorporate the population dimension inherent to public health and all relevant social and political determining factors. ${ }^{74}$ Thus, well-developed health systems encompass not only the spectrum of individual care (primary health care, hospital services, etc.) and all public health services, but also the financing of the system (fee and/or tax based). WHO enumerates four key functions for health systems: service provision; resource generation; financing; and stewardship. $^{75}$ 
Current threats to our populations and the planet are vital and real. Many opportunities, after an abundance of assessments and analyses since the end of the cold war in the late eighties, have been missed. We have to depart from the old thinking of the $20^{\text {th }}$ century, still concerned with diplomatic, economic, and military power plays, and face the real challenges: the warming climate, the global divides (e.g., population growth, social and health inequity, migration, trade, security) and the missed opportunities (e.g., the recognition of health as a basic human right, the Millennium Development Goals, the implementation of the Alma-Ata Declaration on Primary Health Care, the improvement of global aid mechanisms, the strengthening of good governance). This will not become possible without a strong involvement of the civil society. Already by now, about 25 percent of the DAH is channelled through NGOs and this number is increasing. However, NGOs should not only be accountable to their clientele, but also to society in general. Therefore, a code of conduct for NGOs is a first main recommendation and requirement.

Unchecked demographic growth, poverty, the burden of disease, and violent conflicts are interconnected. The demand for basic needs like shelter, clothing, provision of safe food and water, access to adequate (primary) health services, and to education, and last but not least, security in daily life for all populations, does not seem to be an extraordinary or unjustified one. None of these basic requirements to make health a human right a reality have been fulfilled in our world to a degree where we can feel safe. A renewed major effort of the UN community is to be initiated therefore to achieve the MDGs as planned. To simply continue as we have thus far will certainly not be enough.

Resetting global aid has to become part of such a renewed effort towards the MDGs. As of today, aid is highly fragmented, bilateral, and donor dominated with enormous transaction costs, and as a result, not given according to priorities in the recipient countries. It also frequently lacks planned integration and coordination. In fact, most of the financial support is channelled back to the donating countries (via debt repayment, purchase of technical equipment, and international expert charges). The concept of sector wide approaches (SWAp) has to be further developed and made practical to put the receiving governments into the "driver's seat" on the condition of improved governance. To this end, the achievement of the Paris/Accra criteria is essential.

Especially with regard to primary health care, the dominating focus on vertical disease-oriented programs like the Global Fund ${ }^{76}$ can be disastrous, as it often seriously inhibits the development of a sustainable infrastructure 
including training and human resource development. Therefore, the linkage between governments and donors has to be strengthened with a priority for primary health care services instead of secondary and tertiary care.

The migration towards highly developed countries - especially of qualified professionals - cannot simply be stopped without violation of basic human rights. However, there should be an agreed mechanism to compensate the "sending" countries for basic investments into upbringing and education.

The deficit of all good will proposals and actions is a mechanism of enforcement at the global level. However, a good global government is still beyond our horizon. Nevertheless a global awareness in the sense of a New Global Health is a first and essential step on this path, and a participatory approach is the only way open to us.

Conflicts of interest: None declared.

\section{REFERENCES}

1. Basch, PF: Textbook of International Health. $2^{\text {nd }}$ edition, Oxford University Press, New York and Oxford 1999: p.33.

2. Chadwick E. Report of the sanitary condition of the labouring population of Great Britain. A supplementary report on the results of a special inquiry into the practice of internment towns. London: Printed by R. Clowes \& Sons for Her Majesty's Stationery Office; 1843. Available from URL: http://www. archive.org/details/reportonsanitary00chaduoft or http://www.deltaomega.org/ ChadwickClassic.pdf (Accessed 19 May, 2010).

3. Howard-Jones, N.: The scientific background on the international sanitary conferences, 1851-1938. Geneva: World Health Organization; 1975. Available from URL: http://whqlibdoc.who.int/publications/1975/14549_eng.pdf (Accessed 30 March, 2010).

4. Sachs J. Report of the Commission on Macroeconomics and health: investing in health for economic development. Geneva: World Health Organization; 2001. Available from URL: http://whqlibdoc.who.int/publications/2001/ 924154550X.pdf (Accessed 30 March, 2010).

5. World Health Organization. Declaration of Alma Ata, 1978. International Conference on Primary Care, Alma Ata, Russia, 1978. Available from URL: http://www.who.int/hpr/NPH/docs/declaration_almaata.pdf (Accessed 30 March, 2010).

6. US Census Bureau International Data Base (IDB). World population. Available from URL: http://www.census.gov/ipc/www/idb/worldpop.php (Accessed 25 April, 2010). 
7. Kent MM, Haub C. Global demographic divide. Popul Bull. 2005;60:3-24. Available from URL: http://www.prb.org/pdf06/60.4GlobalDemographicDiv ide.pdf (Accessed 24 April, 2010).

8. Gwatkin DR, Shea Rutstein R, Johnson K, Suliman EA, Wagstaff A, Amouzou A. Socio-economic differences in health, nutrition, and population within developing countries. Second edition, Volumes I - III. Washington (DC): World Bank; 2007. Available from URL: http://siteresources.worldbank.org/ INTPAH/Resources/IndicatorsOverview.pdf (Accessed 24 April, 2010).

9. Mathers CD, Lopez AD Murray CJL. The burden of disease and mortality by condition: data, methods, and results for 2001. In: Lopez AD, Mathers CD, Ezzati M, Jamison DT, editors. Global burden of disease and risk factors. Washington: IBRD; 2006. Available from URL: http://www.ncbi.nlm.nih. gov/bookshelf/picrender.fcgi?book=gbd \&part=A176\&blobtype $=$ pdf (Accessed 19 May, 2010).

10. National Institute of Allergy and Infectious Diseases: Emerging and re-emerging infectious diseases: List of NIAID Emerging and Re-emerging Diseases. Available from URL: http://www.niaid.nih.gov/topics/emerging/list.htm/ . (Updated December, 2009 and accessed 31 March, 2010).

11. Commission on Social Determinants in Health. Closing the gap in a generation: Health equity through action on the Social Determinants of Health. The Final Report of the WHO Commission on Social Determinants of Health. Geneva: World Health Organization; 2008. Available from URL: www.who.int/social_ determinants http://whqlibdoc.who.int/publications/2008/9789241563703_ eng.pdf (Accessed 24 April, 2010).

12. Mackenbach, JP, Meerding WJ, Kunst, AE. Economic implications of socioeconomic inequalities in health in the European Union. Luxembourg: Health and Consumer Protection Directorate General, European Commission; 2007. Available from URL: http://ec.europa.eu/health/ph_determinants/socio_ economics/documents/socioeco_inequalities_en.pdf (Accessed 24 April, 2010).

13. La Veist TA, Gaskin DJ, Richard P. The economic burden of health inequalities in the United States. Joint Center for Political and Economic Studies, 2009. Available from URL: http://www.jointcenter.org/publications_recent_publications/ health/the_economic_burden_of_health_inequalities_in_the_united_states (Accessed 24 April, 2010).

14. Cleland JG, van Ginneken JK. Maternal education and child survival in developing countries: the search for pathways of influence. Soc Sci Med. 1988; 27:1351-68.

15. UNICEF. State of the World's Children 2004. UNICEF, New York. Available from URL: www.unicef.org/sowc04/ (Accessed 19 May, 2010).

16. Health in Israel, 2001. Jerusalem: State of Israel Ministry of Health; 2001.

17. Health in Israel, 2005. Jerusalem: State of Israel Ministry of Health; 2005. Available from URL: http://www.health.gov.il/pages/default.asp?maincat=2 \&catid=653\&pageid=3607 (Accessed 25 April, 2010). 
18. Quality indicators for community health in Israel. Public report for 2005-2007. Jerusalem: State of Israel Ministry of Health. Available from URL: http:// www.israelhpr.org.il/english/ (Accessed 24 April, 2010).

19. Hart JT. The inverse care law. Lancet. 1971;297:405-12.

20. Sequist TD, Fitzmaurice GM, Marshall R, Shaykevich S, Safran DG, Ayanian JG. Physician performance and racial disparities in diabetes mellitus care. Arch Intern Med. 2008;168(11):1145-51.

21. Epstein L. (editor) Culturally appropriate health care by culturally competent health professionals. International Workshop Report. Jerusalem: Israel National Institute for Health Policy and Health Services Research; 2008. AvailablefromURL:http://www.israelhpr.org.il/FileServer/daf11be9ddbcd17 dfea47b5583fd61f2.pdf (Accessed 24 April, 2010).

22. UNHCR. 2008 Global Trends: Refugees, Asylum-seekers, Returnees, Internally Displaced and Stateless Persons. Country Data Sheets, 16 June 2009. UNHCR. Available from URL: http://www.unhcr.org/4a375c426.html or http://www.acnur.org/biblioteca/pdf/7096.pdf (Accessed 19 May, 2010).

23. Department of Social and Economic Affairs, Population Division. Trends in total migrant stock: the 2005 revision. New York: United Nations; 2005. Available from URL: http://www.un.org/esa/population/publications/migration/ UN_Migrant_Stock_Documentation_2005.pdf (Accessed 24 April, 2010).

24. World Bank. Migration and remittances data: migration and development brief 5: Revisions to remittance trends, 2007. Available from URL: http://siteresources. worldbank.org/INTPROSPECTS/Resources/334934-1110315015165/MD_ Brief5.pdf (Accessed 30 March, 2010).

25. National Center for Geographic Information and Analysis. The global demography project. Available from URL: http://www.ncgia.ucsb.edu/pubs/gdp/pop.html (Accessed 30 March, 2010).

26. Seeger JR. Research on urban health - the priorities and approaches. In: Harpham T. and Tanner M., editors: Urban health in developing countries. Progress and prospects. London: Earthscan; 1995. pp. 64-81.

27. Gurgand M. Book review: Zhang M. China's poor regions rural-urban migration, poverty, economic reform and urbanization: London: Routledge/Curzon; 2003. China Perspectives. 2006; September-October: no.67. Available from URL: http://chinaperspectives.revues.org/document1055.html (Accessed 23 April, 2010).

28. Ravallion M, Chen S, Sangraula P. New evidence on the urbanization of global poverty. Popul Devel Rev. 2007; 33:41:557-701. Available from URL: http:// www.jstor.org/pss/25487618 (Accessed 24 April, 2010).

29. Cornelius-Taylor B, Handajani YS, Jordan S, Köhler G, Korff R, Laaser U, et al. Urbanisation and public health: a review of the scientific literature. In: Strohmeier KPG, Köhler G, Laaser U, editors. Urban violence and health: determinants and management. A Study in Jakarta, Karachi and Conurbation Ruhrgebiet. Lage: Hans Jacobs-Verlag; 2001: 31-77. Available from URL: 
http://whqlibdoc.who.int/publications/2002/3932136829_(part1).pdf\#page=31 (Accessed 24 April, 2010).

30. World Federation of Public Health Associations. Resolution. Ethical restrictions on international recruitment of health professionals from low-income countries. Geneva: World Federation of Public Health Associations; 2005. Available from URL: http://www.wfpha.org/Archives/05_policy_Recruitment.pdf (Accessed 24 April, 2010).

31. Mejia A. Migration of physicians and nurses: a world wide picture. Bull World Health Organ.2004;82:8. Reprinted with permission of International J. Epidemiol. Available from URL: http://www.who.int/bulletin/volumes/ 82/8/ 626.pdf (Accessed 25 April, 2010).

32. World Bank. High level forum on the MDGs. Addressing Africa's health workforce crisis: an avenue for action. Abuja, December 2004. Available from URL: http://info.worldbank.org/etools/docs/library/206812/AfricasWorkforceHLF\% 20Abuja.pdf (Accessed 9 April, 2010).

33. Chen L, Evans T, Anand S, Boufford JI, Brown H, Chowdhury M, et al. Human resources for health: overcoming the crisis. Lancet. 2004, 364:1984-90. Available from URL: http://www.thelancet.com/journals/lancet/article/PIIS 0140-6736(04)17482-5/fulltext (Accessed 30 March, 2010).

34. United Nations. The universal declaration of human rights. Available from URL: http://www.un.org/en/documents/udhr/ (Accessed 30 March, 2010).

35. Friedman E. An action plan to prevent brain drain: building equitable health systems in Africa. Boston MA: June, 2004. Available from URL: http:// physiciansforhumanrights.org/library/documents/reports/report-2004-july. pdf (Accessed 30 March, 2010).

36. World Federation of Public Health Associations. Available from URL: http:// www.wfpha.org/Archives/05_policy_Recruitment.pdf (Accessed 25 April, 2010).

37. Whelan A, Arkles R, Dewdney J, Zwi A. International movement of skilled health professionals: ethical policy challenges for developed nations, Harvard Health Policy Review. 2004;5:2. Available from URL: http://www.hcs.harvard. edu/ epihc/currentissue/fall2004/whelan_arkles_dewdney_zwi.pdf(Accessed 23 April, 2010).

38. Mensah K, Mackintosh M, Henry L. The 'skills drain' of health professionals from the developing world: a framework for policy formulation. London: Medact; February 2005. Available from URL: http://www.medact.org/content/Skills\% 20drain/Mensah\%20et\%20al.\%202005.pdf (Accessed 31 March, 2010).

39. World Health Organization. International recruitment of health personnel: draft global code of practice. Report by the Secretariat. Geneva: World Health Organization; 2008. Available from URL: http://www.who.int/gb/ebwha/ pdf_files/EB124/B124_13-en.pdf (Accessed 31 March, 2010).

40. Shaffer E. World Federation Public Health Associations. Global trade and public health. World FPHA position paper. J Public Health Policy. 
2007;28:141-6. Available from URL: http://www.phaa.net.au/documents/ submission_ph_int_world_fed_2007.pdf (Accessed 25 April, 2010).

41. General Agreement on Trade in Services (GATS). Objectives, coverage and disciplines. Geneva: World Trade Organization. 2009. Available from URL: http://www.wto.org/english/thewto_e/whatis_e/tif_e/agrm6_e.htm (Accessed 29 March, 2010).

42. Banoob SN. Minimizing the health impacts of the global financial crisis. J Public Health Pol. 2009;30/2: 243-7.

43. Lin JY. The impact of the financial crisis on developing countries. World Bank Res Dig. 2009;3:7-8. Available from URL: http://crisistalk.worldbank.org/files/ Oct_31_JustinLin_KDI_remarks.pdf (Accessed 23 April, 2010).

44. Buvnic M. The global financial crisis: assessing vulnerability for women and children, identifying policy responses. World Bank. February 2009. Available from URL: http://pslforum.worldbankgroup.org/docs/WBFinancialCrisis.doc (Accessed 23 April, 2010).

45. Bhutta ZA, Bawany FA, Feroze A, Rizvi E. Impact of the food and economic crisis on child health and nutrition. December 2008 - draft working paper prepared for the UNICEF Conference, East Asia and Pacific Islands Singapore 2009. Available from URL: http://www.unicef.org/eapro/Crisis_and_Child_ Health_Nutrition_ZB.pdf (Accessed 29 March, 2010).

46. World Health Organization: The Partnership for Maternal Newborn and Child Health. Financial crisis and global health: report of a high level consultation. Geneva: World Health Organization; 2009. Available from URL: http:// www.who.int/pmnch/topics/economics/200901_who/en/ (Accessed 25 April, 2010).

47. World Federation of Public Health Associations. International debt relief. Available from URL: http://www.wfpha.org/Archives/01.19\%20International\% 20Debt\%20Relief.pdf (Accessed 25 April, 2010).

48. United Nations. The Millennium Development Goals report 2009. New York: United Nations; 2009. Available from URL: http://www.un.org/ millenniumgoals/pdf/MDG\%20Report\%202009\%20ENG.pdf (Accessed 1 April, 2010).

49. Bourguignon F, Bénassy-Quéré A, Dercon S, Estache A, Gunning JW, Ravi Kanbur R, et al. Millennium Development Goals at midpoint: where do we stand and where do we need to go? Brussels and Luxembourg: European Commission; 2008. http://ec.europa.eu/development/icenter/repository/ mdg_paper_final_20080916_en.pdf (Accessed 1 April, 2010).

50. United Nations General Assembly. Resolution A 55/2: United Nations Millennium Declaration. Available from URL: http://www.un.org/ millenniumgoals/pdf/MDG\%20Report\%202009\%20ENG.pdf (Accessed 30 March, 2010).

51. International Conference Dedicated to the $30^{\text {th }}$ Anniversary of the Alma Ata Declaration on Primary Health Care. Almaty, Kazakhstan. Available from 
URL: http://www.who.int/mediacentre/events/meetings/alma_ata/en/index. html (Accessed 17 November, 2009).

52. World Health Organization. World health report 2008: primary health care now more than ever. Geneva: World Health Organization; 2008. Available from URL: http://www.who.int/whr/2008/whr08_en.pdf (Accessed 1 April, 2010).

53. Tarimo E, Webster EG. Primary health care concepts and challenges in a changing world: Alma-Ata revisited. Geneva: World Health Organization; 1994.

54. World Health Organization. Primary health care 21: everybody's business. Report of an international meeting to celebrate 20 years after Alma-Ata, Almaty, Kazakhstan, 27-28 November, 1998. Geneva: World Health Organization; 2000. Available from URL: http://www.whqlibdoc.who.int/ hq/2000/WHO_EIP_OSD_00.7pdf (Accessed 23 April, 2010).

55. Avsall JE. The Alma-Ata declaration: 20 years of impact on the European Region of WHO. In: Primary health care 21: everybody's business. Geneva: World Health Organization; 2000. Available from URL: http://www. whqlibdoc.who.int/hq/2000/WHO_EIP_OSD_00.7pdf (Accessed 23 April, 2010).

56. Mahler H. Why Alma-Ata in 1978? In: Primary health care 21: everybody's business. Geneva: World Health Organization; 2000. Available from URL: http://www.whqlibdoc.who.int/hq/2000/WHO_EIP_OSD_00.7pdf(Accessed 23 April, 2010).

57. Kark SL, Kark E. Promoting community health - from Pholela to Jerusalem. Johannesburg, South Africa: Witwatersrand University Press, 1999.

58. Mullan F, Epstein L. Community oriented primary care: new relevance in a changing world. Am. J. Public Health 2002;92:1748-1755. Available from URL: http://www.ncbi.nlm.nih.gov/pmc/articles/PMC1447316/\#_secid515650 (Accessed 1 April, 2010).

59. Epstein L, Gofin J, Gofin R, Neumark Y. The Jerusalem experience: three decades of service, research, and training in community oriented primary care. A J Public Health. 2002;92:1717-21. Available from URL: http:// www.ncbi.nlm.nih.gov/pmc/articles/PMC1447316/\#_secid515650 (full text). (Accessed 1 April, 2010).

60. Rittenhouse DR, Shortell SM, Fisher ES. Primary care and accountable care two essential elements of delivery system reform. N Engl J Med. 2009; 361:2301-3.

61. Shortell SM, Gillies R, Wu F. US innovations in healthcare delivery. Public Health Reviews 2010;32:190-212.

62. Tulchinsky TH, Varavikova EA. What is the "New Public Health"? Public Health Reviews 2010;32:25-53.

63. Bangdiwala SI, Fonn S, Tollman S, Okoye O. Workforce resources for health in developing countries. Public Health Reviews 2010;32:296-318.

64. United Nations. Report of the international conference on financing for development, Monterrey, Mexico. New York (NY): United Nations; 2002. 
Available from URL: http://www.un.org/ga/search/view_doc.asp?symbol=A/ CONF.198/11\&Lang=E (Accessed 1 April, 2010).

65. Global Issues: http://www.globalissues.org/article/35/us-and-foreign-aidassistance\# ForeignAidNumbersinChartsandGraphs (Accessed 9 April, 2010).

66. Ravishankar N, Gubbins P, Cooley RJ, Leach-Kemon K, Michaud CM, Jamison,DT, et al. Financing of global health: tracking development assistance for health from 1990 to 2007. Lancet 2009;373:2113-24.

67. Bornhoft F,Knaup P. You are overtaxed. Der Spiegel 40/2008:42-44; 29 September, 2008. Available from URL: http://www.spiegel.de/spiegel/ print/d-60666807.html (Accessed 9 April, 2010).

68. UN data Physician density per 10,000 population. East Timor physician coverage. Available from URL: http://data.un.org/Data.aspx?d=WHO\&f= inID\%3AHSR02 (Accessed 9 April, 2010).

69. Deutscher E, Fyson S. Committing to effective aid: why can't donors walk their talk? Outreach. February, 2009. (World Bank Group) Available from URL: http://www1.worldbank.org/devoutreach/articleid522.html (Accessed 9 April, 2010).

70. Council of Europe, Committee of experts on good governance in health systems (SP-GHC): Preliminary draft explanatory report. Strasbourg, 28 May, 2009.

71. Cassels A. A guide to sector-wide approaches for health development: Concepts, issues and working arrangements. Geneva: World Health Organization; 1997.

72. Brown A, Foster M, Norton A, Naschold F. The status of sector wide approaches. Overseas Development Institute, Working Paper 142: 2001.

73. HLSP Institute: Sector wide approaches: a resource document for UNFPA staff. London: HSLP; 2005. Available from URL: http://www.unfpa.org/upload/ lib_pub_file/626_filename_swap-unfpa-resource-2005\%20.pdf (Accessed 25 April, 2010).

74. Council of Europe, Committee of Ministers. Recommendations CM/ Rec (2010) 6 of the Committee of Ministers to member states on good governance in health systems. March 2010. Available from URL: https://wcd.coe.int/ ViewDoc.jsp?id $=1608361 \&$ Site $=$ CM\&BackColorInternet $=$ C3C3C3\&Back ColorIntranet=EDB021\&BackColorLogged=F5D383 (Accessed 25 April, 2020).

75. World Health Organization: Health Systems. Available from URL: http://www. who.int/topics/health_systems/en/ (Accessed 9 April, 2010).

76. Borisch B. Global health initiatives and the new dichotomy in health systems. J of Public Health Policy: The federation's pages 2010;31:100-109. Available from URL: http://www.palgrave-journals.com/jphp/journal/v31/n1/full/jphp 200954a.html (Accessed 24 April, 2010). 